\title{
Interlocking Modular Insulation Panels Manufactured with Mediterranean Pinewood and Cork ${ }^{\dagger}$
}

\author{
Pau Brunet-Navarro 1,* , Salvador Gilabert Sanz 1, Melchor Monleón Doménech 2, Miguel Redón Santafé ${ }^{1}$, \\ Eva Hermoso ${ }^{3}$, Mariola Sánchez-González ${ }^{3}$, Emilio Luengo ${ }^{4,5}$, Zaratiana Mandrara ${ }^{6}$, Jorge Gominho ${ }^{7}$ and \\ José V. Oliver-Villanueva ${ }^{1}$
}

Citation: Brunet-Navarro, P.; Gilabert Sanz, S.; Monleón Doménech, M.; Redón Santafé, M.; Hermoso, E.; Sánchez-González, M.; Luengo, E.; Mandrara, Z.; Gominho, J.; Oliver-Villanueva, J.V. Interlocking Modular Insulation Panels Manufactured with Mediterranean Pinewood and Cork. Environ. Sci. Proc. 2021, 3, 86. https://doi.org/10.3390/IECF202008072

Academic Editors: Angela Lo Monaco, Cate Macinnis-Ng and Om P. Rajora

Published: 13 November 2020

Publisher's Note: MDPI stays neutral with regard to jurisdictional claims in published maps and institutional affiliations.

Copyright: (C) 2020 by the authors. Licensee MDPI, Basel, Switzerland. This article is an open access article distributed under the terms and conditions of the Creative Commons Attribution (CC BY) license (http://creativecommons.org/licenses/by/4.0/).
1 Institute of Information and Communication Technologies, Universitat Politècnica de València, 46022 Valencia, Spain; salgisa1@ega.upv.es (S.G.S.); miresan@agf.upv.es (M.R.S.); joolvil@upv.es (J.V.O.-V.)

2 Autonomous Employee, 46008 Valencia, Spain; mel@ctav.es

3 Departamento de Productos Forestales, Centro de Investigación Forestal, Instituto Nacional de Investigación y Tecnología Agraria y Alimentaria, 28040 Madrid, Spain; hermoso@inia.es (E.H.); msanchez@inia.es (M.S.-G.)

4 Asociación de Investigación de las Industrias de la Madera, 28013 Madrid, Spain; e.luengo@aitim.es

5 Escuela Técnica Superior de Ingeniería de Montes Forestal y del Medio Natural, Universidad Politécnica de Madrid, 28040, Madrid, Spain

6 Institut Technologique Forêt Cellulose Bois-construction Ameublement, 77420, Bordeaux, France; zaratiana.mandrara@fcba.fr

7 Instituto Superior de Agronomia, University of Lisbon, 1349017 Lisbon, Portugal; jgominho@isa.ulisboa.pt

* Correspondence: brunet@upv.es; Tel.: +34-963-877-274

+ Presented at the 1st International Electronic Conference on Forests - Forests for a Better Future: Sustainability, Innovation, Interdisciplinarity, 15-30 November 2020; Available online: https://iecf2020.sciforum.net.

Abstract: Economic profitability of harvested softwood in Southwestern Europe is limited for low quality logs. Some social and environmental consequences of low incomes of rural activities are rural depopulation and accumulation of biomass in unmanaged forests. The energy efficiency of buildings could be improved as construction material employing local bioresources that are currently used to manufacture products of low added value. Here, the IMIP project (Innovative EcoConstruction System Based on Interlocking Modular Insulation Wood \& Cork-Based Panels) aimed to support the change towards a low carbon economy using bioproducts (pinewood and cork) for smart, sustainable, and inclusive growth with a special focus on the public construction sector is presented. The main objective of the IMIP project is to design, validate and implement an innovative ecological construction system based on natural biological materials to improve energy efficiency in public buildings from the construction, use and demolition phases. The project also develops a tool to professionals from the construction sector (architects and engineers) and researchers to assess the carbon footprint of buildings. The products of the project have the ambition to improve the economic, social and environmental situation of rural areas of Southwestern Europe.

Keywords: wood-based construction; cork; climate change mitigation; harvested wood products; production chains; circular economy; rural areas

\section{Introduction}

Socio-economic challenges, such as rural depopulation and unemployment, are shared throughout the south-western region of Europe [1,2]. Population and economic activity in the region are not distributed homogeneously. Most of the inhabitants live in big cities nearby the sea line where the industry is concentrated [3]. Young people from inland rural areas move towards urban areas looking for job opportunities. Small and medium-sized enterprises (SMEs) in rural inland areas, mainly managed by elders, have not the capacity to invest on innovation and become old-fashioned [4]. 
The abandonment of rural areas has had consequences on forests. Less productive agricultural crops or those with difficult access are being abandoned and forest occupies them [5]. Also, traditional use of biomass as firewood has been substituted by fossil energies since the middle of the 20th century. Because of this lower economic and social activity, forests become unmanaged and biomass accumulates creating horizontal and vertical continuity what increases the risk of natural disasters like big wildfires [6,7].

The South-Western Europe is one of the world most responsive regions to climate change $[8,9]$. Forecasted climate change in southern European countries are an increase of temperatures and severer summer droughts [10]. Desertification and soil erosion are current problems that will move northward under future forecasted scenarios of climate change. These changes together with current conditions of unmanaged forests increase the risk of wildfires [11]. The overall consequences may have not only environmental impacts (loss of biodiversity, soil erosion, sudden and uncontrolled emissions of sequestered carbon etc.) but also direct social impacts including a reduction of water and air quality $[9,10]$.

The large extensions of vast forest areas in the South-West region of Europe and the high concentration of unused biomass devise an opportunity to produce new wood-based products from it. A smart growth focused on the promotion of a circular bio-economy based on knowledge and innovation is an excellent opportunity especially for SMEs in the region. In addition, the cooperation between businesses to start new economic activities of high added value in rural areas may contribute to the creation of new job opportunities and increase social cohesion [12]. Also, the removal of such biomass will reduce the risk of wildfires in Mediterranean areas and improve forest management [13]. Other lignocellulosic materials from the region like cork can be employed to produce innovative products of high added value [14].

In Europe, the building sector which represents $42 \%$ of the energy consumed, $35 \%$ of total greenhouse gas emissions, $50 \%$ of the materials consumed, and $30 \%$ of the water consumed [15], is a strategic sector with high potential benefits to use local natural resources like wood and cork. Some regions in the South-West Europe play an important role as leaders on industrial production on specific sectors showing a resilient capacity in front of the economic crisis of the last years. Their economic, industrial and scientific dynamism contributed to have the lowest unemployment rates in this region. The forestbased industry could use the example of these sectors and reduce the impact of the global crisis on the sector through cooperation, for instance, through clusters, specialized associations of companies and professionals, and centers of excellence [16] to build the base of industrial production in the region.

Wood and cork are local natural resources whose technical characteristics make them excellent raw materials for construction. Wood is not simply a low-density biological material whose processes of industrial transformation and production emit less greenhouse gas emissions than its competitors, but it also stores atmospheric carbon. In south-western Europe there are few wooden buildings in comparison to other European regions [17]. Therefore, it is the European region where the potential climate change mitigation through the substitution of materials may have the biggest impact.

Taking into account all these aspects, the Interreg Sudoe IMIP project (Innovative Eco-Construction System Based on Interlocking Modular Insulation Wood \& Cork-Based Panels) aims to support the change towards a low carbon economy using bioproducts (wood and cork) for smart, sustainable, and inclusive growth with a special focus on the public construction sector.

\section{Methods}

An international consortium of nine partners from Spain, France and Portugal with different legal natures and expertise collaborate to improve the energy efficiency policies in public buildings and homes through the implementation of networks and joint experimentation. The main objective of IMIP is to design, validate and implement an innovative 
ecological construction system based on natural biological materials to improve energy efficiency in public buildings from the construction, use and demolition phases. Interlocking modular insulation panels manufactured with Mediterranean pinewood and cork will be designed and prototypes manufactured. These innovative panels and prefabricated construction solutions (insulating partitions, frameworks, floors and light roof structures) will be tested on certified labs to analyze their technical behavior in terms of mechanical performance, durability, acoustic and thermal insulation and energy efficiency. Technical and economic evaluation as well as an environmental assessment will be carried out.

Another relevant objective of the project is to provide a tool to professionals from the construction sector and researchers to assess the carbon footprint of buildings, specifically developing BIM (Building Information Modeling) tools.

\section{Results and Discussion}

One of the main expected results is an interconnected modular system of insulating panels made of pinewood (Pinus pinaster Aiton. or Pinus halepensis Mill.) and cork (Quercus suber L.) to improve energy efficiency of buildings, including their entire life cycle. The panels will be composed by a three-layered Cross Laminated Timber (CLT) on each external side and an inner layer of cork. When building design will require it, panels will include internal ribs to improve technical performance.

After prototype testing, this system will be applied in public buildings through four pilot actions: two in Spain, one in France and one in Portugal. The pilot action in Portugal will be temporal aiming to test the assembly and disassembly of panels and its transport for its reutilization. The pilot action in France will allow to test panels performance against fire. One of the pilot actions in Spain will demonstrate the possibility to employ exclusively this new construction system to build a new building. The other pilot action in Spain will demonstrate how panels can complement a new building made with a different construction system.

Another expected result is the development and implementation of a specific plugin for BIM tools, which will be a technical support for architects and engineers in building projects. This plug-in will complement the analysis of environmental benefits of these innovative bioproducts used in construction (carbon storage and substitute effect).

In addition, some of the most relevant products will be a roadmap towards an increased use of wood and cork in public buildings of South-West Europe, a roadmap for improving energy efficiency in public buildings through use of local bio-resources, and a technical sheet to be included in official recognized tools for policy implementation. Other products will be training courses, scientific publications, or the methodology description for panel installation.

This project will create several opportunities for regional challenges. The promotion of smart growth focused on promoting a circular bioeconomy based on knowledge and innovation is an excellent opportunity for SMEs located in rural areas of the south-western Europe. Cooperation between companies and research organizations to start new high value-added economic activities in rural areas can contribute to create new job opportunities and increase social cohesion.

The high concentration of unused wood and cork resources in the region creates an opportunity to be used as raw material to produce innovative wood and cork-based products. Furthermore, the harvest of this biomass will reduce the risk of wildfires and will contribute to the improvement of sustainable forest management. The construction sector, due to its high impact, is a tractor sector with high potential benefits for the use of local renewable natural resources such as wood or cork.

This added value endowment of forest products in turn represents an opportunity for rural development and employment for local populations that could reverse the serious trend of depopulation suffered by rural communities. 


\begin{abstract}
Author Contributions: Conceptualization, P.B.-N., J.V.O.-V., M.R.S., S.G.S. and M.M.D.; writingoriginal draft preparation, P.B.-N.; writing - review and editing, J.V.O.-V., E.H., M.S.-G., E.L., J.G. and Z.M.; funding acquisition, P.B.-N. and J.V.O.-V. All authors have read and agreed to the published version of the manuscript.
\end{abstract}

Funding: This research was funded by the Interreg SUDOE program as part of the European Regional Development Found (ERDF), grant number SOE3/P3/E0963.

Conflicts of Interest: The authors declare no conflict of interest.

\title{
References
}

1. Hart, K.; Allen, B.; Lindner, M.; Keenleyside, C.; Burgess, P.; Eggers, J.; Buckwell, A. Land as an Environmental Resource; Report Prepared for DG Environment, Contract No ENV.B.1/ETU/2011/0029; Institute for European Environmental Policy: London, UK, 2012; p. 240.

2. Perpiña Castillo, C.; Jacobs-Crisioni, C.; Kavalov, B.; Lavalle, C. Socio-economic and demographic trends in EU rural areas: An indicator-based assessment with LUISA territorial modelling platform. In Proceedings of the 5th International Conference on Geographical Information Systems Theory, Applications and Management (GISTAM 2019), Heraklion, Crete, Greese, 3-5 May 2019; pp. 250-258, doi:10.5220/0007739902500258.

3. Collantes, F.; Pinilla, V.; Sáez, L.A.; Silvestre, J. Reducing Depopulation in Rural Spain: The Impact of Immigration. Popul. Space Place 2014, 20, 606-621, doi:10.1002/psp.1797.

4. Smit, S.; Tacke, T.; Lund, S.; Manyika, J.; Thiel, L. The Future of Work in Europe: Automation, Workforce Transitions, and the Shifting Geography of Employment; McKinsey Global Institute: Amsterdam, The Netherland, 2020; p. 52.

5. Lasanta, T.; Arnáez, J.; Pascual, N.; Ruiz-Flaño, P.; Errea, M.P.; Lana-Renault, N. Space-time process and drivers of land abandonment in Europe. Catena 2017, 149, 810-823, doi:10.1016/j.catena.2016.02.024.

6. Lasanta, T.; Nadal-Romero, E.; Arnáez, J. Managing abandoned farmland to control the impact of re-vegetation on the environment. The state of the art in Europe. Environ. Sci. Policy 2015, 52, 99-109, doi:10.1016/j.envsci.2015.05.012.

7. Viedma, O.; Moreno, J.M.; Rieiro, I. Interactions between land use/land cover change, forest fires and landscape structure in Sierra de Gredos (Central Spain). Environ. Conserv. 2006, 33, 212-222.

8. Giorgi, F. Climate change hot-spots. Geophys. Res. Lett. 2006, 33, doi:10.1029/2006GL025734.

9. Stocker, T.F.; Qin, D.; Plattner, G.-K.; Tignor, M.; Allen, S.K.; Boschung, J.; Nauels, A.; Xia, Y.; Bex, V.; IPCC; et al. Climate Change 2013: The Physical Science Basis; Cambridge University Press: Cambridge, UK; New York, NY, USA, 2013; ISBN 978-1-107-66182-0.

10. Beniston, M.; Stephenson, D.B.; Christensen, O.B.; Ferro, C.A.T.; Frei, C.; Goyette, S.; Halsnaes, K.; Holt, T.; Jylhä, K.; Koffi, B.; et al. Future extreme events in European climate: An exploration of regional climate model projections. Clim. Chang. 2007, 81, 71-95, doi:10.1007/s10584-006-9226-z.

11. Vilar, L.; Camia, A.; San-Miguel-Ayanz, J. Modelling socio-economic drivers of forest fires in the Mediterranean Europe. In Modelling Socio-Economic Drivers of Forest Fires in the Mediterranean Europe; Imprensa da Universidade de Coimbra: Coimbra, Portugal, 2014; ISBN 978-989-26-0884-6.

12. Dudwick, N. The Relationship between Jobs and Social Cohesion: Some Examples from Ethnography; Department for International Development: London, UK, 2012.

13. Verkerk, P.J.; Martinez de Arano, I.; Palahí, M. The bio-economy as an opportunity to tackle wildfires in Mediterranean forest ecosystems. For. Policy Econ. 2018, 86, 1-3, doi:10.1016/j.forpol.2017.10.016.

14. Silva, S.P.; Sabino, M.A.; Fernandes, E.M.; Correlo, V.M.; Boesel, L.F.; Reis, R.L. Cork: Properties, capabilities and applications. Int. Mater. Rev. 2005, 50, 345-365, doi:10.1179/174328005X41168.

15. Hurmekoski, E. How Can Wood Construction Reduce Environmental Degradation? European Forest Institute: Joensuu, Finland, 2017.

16. European Commission. Commission staff working document-A blueprint for the EU forest-based industries (woodworking, furniture, pulp \& paper manufacturing and converting, printing). Comm. Staff Work. Doc. 2013, $2013,41$.

17. Hurmekoski, E.; Jonsson, R.; Nord, T. Context, drivers, and future potential for wood-frame multi-story construction in Europe. Technol. Forecast. Soc. Chang. 2015, 99, 181-196, doi:10.1016/j.techfore.2015.07.002. 